\title{
Hematopoietic stem cell transplantation in a patient with osteopetrosis and mutation in CLCN7: long-term follow-up
}

\author{
José F. Gaytán-Morales ${ }^{1}$, Iván Castorena-Villa', Fredenet O. Mendoza-Camargo', \\ Dolores C. Cortés-Flores ${ }^{1}$, Yazmin A. Gómez-Domíguez', Pamela D. Montenegro-Chahar', \\ Paulina García-Maldonado ${ }^{1}$, and Israel Parra-Ortega ${ }^{2 *}$ \\ ${ }^{1}$ Servicio de Trasplante de Médula Ósea; ${ }^{2}$ Departamento de Laboratorio Clínico. Hospital Infantil de México Federico Gómez, Mexico City, Mexico
}

\begin{abstract}
Background: Osteopetrosis is a rare hereditary bone dysplasia characterized by insufficient osteoclast activity that results in increased bone mineral density. Hematopoietic stem cell transplantation (HSCT) can reverse skeletal abnormalities and restore hematopoiesis. Case report: We present the case of a 3-year and 2-month-old male patient with the diagnosis of osteopetrosis. The patient underwent allogeneic HSCT (Allo-HSCT) using 100\% compatible bone marrow from a related donor and received a myeloablative conditioning regimen and a CD34 cell dose $\left(4.7 \times 10^{7} / \mathrm{kg}\right)$. In the early post-transplant, frequent complications such as pneumonitis, hypercalcemia, and hyperphosphatemia ocurred. With a suitable granulocytic graft and chimerism of $100 \%$, it was considered a successful transplant. However, the patient showed a delayed platelet graft treated with a platelet-stimulating factor for 6 months. The patient is currently disease-free, outpatient follow-up, with no data on graft-versus-host disease, and no progressive neurological damage. Conclusions: Osteopetrosis is a childhood disease that requires clinical suspicion and early diagnosis. HSCT is necessary at an early age to prevent disease progression and sensorineural, hematological, and endocrinological functions damage that can lead to death.
\end{abstract}

Key words: Osteopetrosis; Hematopoietic stem cell transplantation; Bone marrow stem cell transplant.

\section{Trasplante de células progenitoras hematopoyéticas en un paciente con osteopetrosis y mutación en CLCN7: seguimiento a largo plazo}

\section{Resumen}

Introducción: La osteopetrosis es una displasia ósea hereditaria poco común, caracterizada por una actividad osteoclástica deficiente que aumenta la densidad mineral ósea. Se considera que el trasplante de células progenitoras hematopoyéticas (TCPH) puede revertir las anormalidades esqueléticas y restaurar la hematopoyesis. Caso clínico: Se presenta el caso de un paciente de sexo masculino, de 3 años y 2 meses de edad, con diagnóstico tardío de osteopetrosis. Se realizó un TCPH alogénico de donador relacionado 100\% compatible con médula ósea. Se utilizaron un régimen de acondicionamiento mieloablativo y una dosis celular de CD34 de $4.7 \times 10^{7} / \mathrm{kg}$ de peso. En el postrasplante temprano, el paciente desarrolló complicaciones como neumonitis, hipercalcemia e hiperfosfatemia. Con un injerto granulocítico adecuado y quimerismo del

Correspondence:

*Israel Parra-Ortega

E-mail: i_parra29@hotmail.com
Date of reception: 10-04-2020

Date of acceptance: 11-07-2020

DOI: 10.24875/BMHIM.20000105
Available online: 02-03-2021

Bol Med Hosp Infant Mex. 2021;78(3):225-233

www.bmhim.com

1665-1146/@ 2020 Hospital Infantil de México Federico Gómez. Published by Permanyer. This is an open access article under the CC BY-NC-ND license (http://creativecommons.org/licenses/by-nc-nd/4.0/). 
$100 \%$ se consideró un trasplante exitoso. Sin embargo, el paciente presentó retraso en el injerto plaquetario, por lo que se administró factor estimulante de plaquetas por 6 meses. Actualmente el paciente se encuentra libre de enfermedad, en seguimiento ambulatorio, sin datos de enfermedad del injerto contra el hospedero y con pruebas de neurodesarrollo sin deterioro neurológico progresivo. Conclusiones: La osteopetrosis es una enfermedad infantil que requiere una sospecha clínica y un diagnóstico temprano, ya que es necesario un TCPH a corta edad como tratamiento para evitar la progresión de la enfermedad y el deterioro de las funciones neurosensoriales, hematológicas y endocrinológicas que puede derivar en la defunción del paciente.

Palabras clave: Osteopetrosis. Trasplante de células progenitoras hematopoyéticas. Trasplante de médula ósea.

\section{Introduction}

Osteopetrosis, also known as marble bone disease, is a rare hereditary bone dysplasia characterized by a decreased resorptive activity of osteoclasts leading to inadequate resorption and abnormal bone turnover, causing an increased bone mineral density and increased risk of fractures ${ }^{1}$. Inadequate bone remodeling produces skeletal deformities, and the lack of bone elasticity coupled with bone fragility increases the risk of fractures ${ }^{2}$. The endochondral bone in the medullary cavity alters hematopoietic function causing life-threatening anemia, thrombocytopenia, and leukopenia.

Alterations in bone restructuring, which produce a narrowing of the bone canals and limits blood supply, can cause neurological disorders ${ }^{3}$. Different gene mutations can cause neurological alterations: the mutation of the T-cell immune regulator 1 (TCIRG1) gene causes neuronal compression, while the mutation of the CLCN7 gene causes significant progressive encephalopathy and retinopathy in some patients ${ }^{4}$.

Clinical suspicion is essential to achieve early diagnosis and timely intervention with allogeneic hematopoietic stem cell transplantation (Allo-HSCT), a curative treatment that can reverse skeletal abnormalities and restore hematopoiesis ${ }^{5}$.

\section{Epidemiology}

Autosomal recessive osteopetrosis incidence is 1 in 250,000 births, with a higher incidence in Costa Rica (3.4 in 100,000 births). In contrast, autosomal dominant osteopetrosis incidence is 1 in 20,000 births $^{6}$.

\section{Classification}

Osteopetrosis has a broad clinical spectrum: from a minimal disease, even asymptomatic, to the severe form known as infantile or malignant osteopetrosis (autosomal recessive), which is life threatening, especially during the first year of life (Table 1).
For decades, before identifying gene mutations affecting osteoclasts activity, osteopetrosis had been categorized depending on clinical characteristics and inheritance patterns. The malignant or infantile osteopetrosis with autosomal recessive inheritance pattern is the most severe form and the one with the earliest presentation. Intermediate osteopetrosis also has an autosomal recessive inheritance pattern, and benign or adult osteopetrosis is inherited in an autosomal dominant pattern.

\section{Clinical description}

The increase in bone mineral density results in particular physical characteristics, such as macrocephaly, craniofacial deformities, and generalized sclerosis. However, the primary involvement is in the bone marrow and central nervous system. The bone marrow's infiltration produces bone marrow failure; thus, hematopoiesis is compromised, and extramedullary hematopoiesis appears, which manifests itself as hepatosplenomegaly.

\section{Etiology}

Osteopetrosis is caused by a failure in osteoclasts' development and function. Furthermore, mutations in at least 10 genes are found in approximately $70 \%$ of patients. This disorder has an autosomal dominant or autosomal recessive inheritance pattern, being the last one the most severe form of presentation?.

Osteoclasts are highly specialized cells derived from mononuclear precursors from the myeloid lineage. Their function is bone resorption, a fundamental process for remodeling and maintaining bone stability and mineral homeostasis.

Some osteopetrosis cases are caused by mutations in genes involved in $\mathrm{pH}$ acidification, which depends on the proper function of V-ATPase and CLCN-7. Homozygous mutations in these genes can cause malignant osteopetrosis. 
Table 1. Characteristics of the different types of osteopetrosis and genetic classification

\begin{tabular}{|c|c|c|c|c|c|c|c|}
\hline Population & Inheritance & $\begin{array}{l}\text { Bone marrow } \\
\text { failure }\end{array}$ & Diagnosis & Clinical features & Prognosis & $\begin{array}{l}\text { Associated genes } \\
\text { ( } \% \text { of presentation) }\end{array}$ & $\begin{array}{l}\text { Life } \\
\text { expectancy }\end{array}$ \\
\hline Adult & $A D$ & No & Incidental & $\begin{array}{l}\text { Asymptomatic. } \\
\text { However, in type I, } \\
\text { there is skull } \\
\text { affection, and in } \\
\text { type II, there is the } \\
\text { involvement of the } \\
\text { cranial base, } \\
\text { vertebrae, pelvis, } \\
\text { and long bones. In } \\
\text { some cases, bone } \\
\text { pain or fractures } \\
\text { have been reported }\end{array}$ & Good & $\begin{array}{l}\text { CA II } \\
\text { RANKL }\end{array}$ & Normal \\
\hline Childhood & $A R$ & Severe & $\begin{array}{l}\text { One year of } \\
\text { age }\end{array}$ & $\begin{array}{l}\text { Blindness, hearing } \\
\text { loss, growth } \\
\text { retardation, frequent } \\
\text { fractures, severe } \\
\text { hypocalcemia, } \\
\text { hydrocephalus, } \\
\text { neurodegeneration }\end{array}$ & Poor & $\begin{array}{l}\text { TCIRG1 }(51-53 \%)^{*} \\
\text { CLCN7 }(13-16 \%)^{* *} \\
\text { OSTM1 }(2-6 \%)^{*}\end{array}$ & $\begin{array}{l}0-10 \text { years } \\
0-3 \text { years } \\
0-2 \text { years }\end{array}$ \\
\hline Intermediate & AR & Variable & $\begin{array}{l}\text { Childhood/ } \\
\text { adolescence }\end{array}$ & $\begin{array}{l}\text { Bone pain, arthritis, } \\
\text { blindness, hearing } \\
\text { loss, osteomyelitis, } \\
\text { anemia }\end{array}$ & Variable & $\begin{array}{l}\text { PLEKHMI } \\
\text { CLCN7 } \\
\text { LRP5 } \\
\text { CA II }\end{array}$ & Variable \\
\hline $\begin{array}{l}\text { Gene and } \\
\text { transcript }\end{array}$ & Location & \multicolumn{3}{|l|}{ Variant } & Genotype & \multicolumn{2}{|l|}{ Classification } \\
\hline CLCN7 & Exon $5 / 25$ & \multicolumn{3}{|c|}{$\begin{array}{l}\text { ENST00000382745.4:c.376C>T } \\
\text { ENSP00000372193.4:p.Arg126Cys } \\
\text { Grch37 (hg19) chr16: } 1510925 \\
\text { Grch38 (hg38) chr16: } 1460924\end{array}$} & Homozygous & \multicolumn{2}{|c|}{$\begin{array}{l}\text { Probably pathogenic variant } \\
\text { Missense variant }\end{array}$} \\
\hline
\end{tabular}

*Percentage of presentation of genes in malignant childhood osteopetrosis.

**Detected in our patient by genetic sequencing.

AR: autosomal recessive; AD: autosomal dominant.

\section{Diagnosis}

The diagnosis of childhood osteopetrosis is based on clinical and radiographic evaluations and confirmed by genetic testing ${ }^{2}$. It is essential to consider the diagnosis based on clinical suspicion and corroborate it by radiography and image studies, where cortical atrophy and generalized sclerosis mainly affecting the skull, pelvis, and spine can be appreciated. The characteristic image of bone within a bone, particularly in vertebrae and phalanges, can be observed. Age of presentation, inheritance, and associated clinical features such as pancytopenia, neurodegeneration, mental retardation, tubular acidosis, neuronal compression, and visual and auditory impairment support the diagnosis.

In case of suspicion, laboratory studies should be requested, such as serum calcium, parathyroid hormone, phosphorus, creatinine, 25-hydroxyvitamin D, and lactic dehydrogenase levels, which provide mineral homeostasis data. Also, a complete blood count with differential is necessary for bone marrow failure evaluation. Bone biopsy is useful for differentiating rich or deficit osteoclasts forms of osteopetrosis; however, it should not be performed routinely and is not essential for diagnosis.

Creatine kinase BB isoenzyme has been detected in patients with malignant osteopetrosis with $\mathrm{CLCN}-7$ mutation; however, its levels do not correlate with the severity of the disease, and normal levels do not exclude the diagnosis ${ }^{8}$.

Finally, the specific mutation must be confirmed by genetic testing to provide follow-up, prognosis, a probable response to treatment, recurrence, and genetic counseling.

Multidisciplinary management of these patients is vital since multiple organs and systems are affected. Endocrinologically, serum calcium levels should be 
monitored since bone cannot mobilize calcium due to the osteoclasts' defect, which causes hypocalcemia and, secondary to this, tetany and seizures.

It is necessary to periodically evaluate patients' visual capacity to detect and control the emergence of major visual complications, such as optic nerve atrophy. Patients often have dental abnormalities, such as delayed or failed tooth eruption, malformation, and easy teeth loss. Fractures and their complications with osteomyelitis are frequent. Therefore, an expert orthopedic surgeon should evaluate patients. Neurologically, developmental delay, compression neuropathies, and craniofacial deformities should be intentionally sought.

Regarding hearing, nerve compression can lead to sensorineural deafness. Concerning hematological complications, pancytopenia is the primary life-threatening condition of patients with osteopetrosis, leading to severe infections and bleeding ${ }^{5}$.

\section{Differential diagnosis}

The differential diagnosis should be made with any disease that causes bone sclerosis, such as berylliosis, myelofibrosis, Paget's disease, and malignant diseases. X-rays may show an increase in bone mineral density; however, compared to osteopetrosis, this alteration improves overtime. When osteopetrosis is diagnosed, it is essential to distinguish the subtype because each has a different evolution, progression, prognosis, and treatment.

\section{Genetic alterations}

The primary characteristic mutation of osteopetrosis is found in the TCIRG1 gene, which encodes the $\alpha 3$ subunit of the vacuolar $\mathrm{H}^{+}$ATPase (V-ATPase), which pumps protons through the membranes, helping to regulate cellular and extracellular $\mathrm{pH}$.

The V-ATPase plays an essential role on the surface of osteoclasts. This protein is embedded in a membrane that contacts the bone's surface and forms a compartment between the osteoclast and the bone surface. Its function is to pump protons into the bone, acidifying it and creating a suitable bone resorption environment ${ }^{9}$. This mutation is responsible for $50 \%$ of patients diagnosed with recessive osteopetrosis ${ }^{10}$.

The CLCN7 gene encodes a chloride channel (CLC-7) that provides electroneutrality during the acidification process $^{4}$. The mutation of this gene is present in $10-15 \%$ of patients with malignant osteopetrosis.
The third gene involved in this disease is OSTM1, which causes a more aggressive disease phenotype, shortening survival.

\section{Treatment}

HSCT is a procedure in which stem cells (HSC) from a disease-free donor are infused into patients with the disease. This procedure is performed to restore bone marrow function. There are different types of HSCT, depending on the type of HSC donor: autologous transplant (donor and recipient are the same subject), allogeneic transplant, which is performed from a donor with human leukocyte antigen (HLA) 100\% compatible with the recipient and can be a related donor (family member) or an unrelated donor (non-family member), and haploidentical transplant, in which the family donor has an HLA 50\% compatible with the recipient.

The initial treatment of osteopetrosis is mainly supportive and focuses on treating the main complications, such as pancytopenia, infections, and bleeding.

Fractures and arthritis require specialized treatment and follow-up since there is usually a delay in consolidation, osteomyelitis, and recurrent fractures.

Developmental delay and seizures associated with normal calcium levels often indicate childhood osteopetrosis. Neurological evaluations, including magnetic resonance imaging (MRI) and electroencephalogram, periodic ophthalmological examinations, including visual evoked potentials, and fundus examination to detect optic nerve atrophy, should be performed as soon as possible.

Hearing function evaluations should also be performed because, initially, neurosensory damage is mild; however, it may contraindicate HSCT as it progresses to severe forms.

Bone marrow failure can be treated initially with platelet and red blood cell concentrates transfusions; however, the definitive treatment of osteopetrosis is Allo-HSCT. In this pathology, HSCT is considered a therapeutic emergency because, as the disease progresses, sensory, visual, and hearing alterations become irreversible if treatment is late.

Transplant-related complications include transplant rejection, delayed graft function, hepatic sinusoidal occlusive syndrome, pulmonary hypertension, and hypercalcemic crises ${ }^{11}$.

It is necessary to keep this disease under consideration when evaluating a patient with multiple dysmorphia, retarded growth and development, as well as sensory alterations, accompanied by metabolic and hematological alterations since timely diagnosis will 
allow to perform an effective treatment and thus avoid a progression of the disease with more significant neurosensory impairment. Highlighting the importance of this pathology's treatment, we present the case of a patient with osteopetrosis treated with an Allo-HSCT, who had a successful evolution, even with a late disease diagnosis and a mild neurosensorial impairment.

\section{Clinical case}

We present the case of a 3-year and 2-month-old male patient from the State of Mexico. In his family medical history, healthy parents with no chronic degenerative diseases or consanguinity, a healthy 8-year-old sister, and no history of cancer, genetic or metabolic diseases, or immunodeficiency were reported.

At 1 year of age, the patient attended the Hospital Infantil de México Federico Gómez (HIMFG) for presenting community-acquired pneumonia (CAP), and later required hospitalizations for the same diagnosis (Fig. 1).

At 3 years of age, he was admitted again for CAP. On physical examination, generalized integument paleness, macrocephaly, hypertelorism, microretrognathia, prominent forehead, telecanthus, trichiasis, prominent eyes, flat nasal bridge, short neck, and narrow chest were observed. The skull X-ray showed the mask sign, characterized by generalized bone hyperdensity, predominantly at the base of the skull, which gave it the appearance of a mask in the orbital region. A chest $X$-ray was performed, observing an increase in bone density at the rib, sternal, and vertebral level. In addition, the bone within a bone sign, which consists of lines parallel to the tibia's cortical bone, was observed in the long bone X-ray. In laboratory studies, bicytopenia was reported in the complete blood count (hemoglobin $5.7 \mathrm{mg} / \mathrm{dl}$, hematocrit $17.7 \%$, leukocytes 13,400 cells $/ \mu \mathrm{L}$, total neutrophils 4020 cells $/ \mu \mathrm{L}$, and platelets 22,000 cells/ $\mu \mathrm{L})$. Therefore, as part of the approach, a bone marrow biopsy was requested, which reported hypocellularity, small intertrabecular spaces with fibrous tissue, and endochondral ossification. Due to the presence of dysmorphic syndrome, the patient required evaluation by the genetics service.

The patient was diagnosed with osteopetrosis at 3 years and 2 months of age, and as part of the evaluation by the HSCT service, the molecular study was carried out using second-generation sequencing in the HIMFG Research Unit. A mutation in the CLCN7 gene was reported, and the patient was classified as a homozygous genotype (Table 1). With this mutation, the patient met the criteria for an Allo-HSCT.
During hospitalization, the patient presented bilateral serous otitis media with secondary conductive hearing loss, for which ventilation tubes were placed. Influenza was detected, requiring antiviral treatment; another event of otitis media with otorrhea occurred, for which the patient required myringotomy and placement of ventilation tubes again.

A skull MRI was performed in the pre-transplant evaluations, where frank cortical atrophy with secondary ventricular dilation associated with its underlying pathology was observed. We detected a slight alteration in the bilateral visual pathways' conduction, together with a normal audiometry report, employing visual evoked potentials. Due to these results and the significant risk of developmental delay, the Infant Development Assessment test was performed, in which the patient met the criteria for risk of developmental delay. In the Battelle developmental test, a total development ratio of 63 was reported, corresponding to an equivalent age of 2 years and 3 months of age (deficit of 1 year and 5 months [37\%]). Finally, the patient was diagnosed with global neurodevelopmental delay.

According to the HSCT protocol of the HIMFG, comorbidities were evaluated by the following services: ophthalmology, endocrinology, cardiology, infectology, otorhinolaryngology, pulmonology, nephrology and gastroenterology, and nutrition. Neurosensory, severe visual, or hearing damage were ruled out. In the admission blood count, before the HSCT, the following results were reported: total leukocytes 5300 cells/ $\mu \mathrm{L}$, total neutrophils 2070 cells $/ \mu \mathrm{L}$, platelets 35,000 cells $/ \mu \mathrm{L}$, and hemoglobin $9.1 \mathrm{mg} / \mathrm{dL}$. At 3 years and 9 months of age, Allo-HSCT was performed from $100 \%$ compatible related donor (sister), using a myeloablative conditioning regimen: on days $-7,-6,-5$, and -4 , the patient received busulfan (1.2 $\mathrm{mg} / \mathrm{kg} / \mathrm{day})$, and on days -3 and -2 , cyclophosphamide $(60 \mathrm{mg} / \mathrm{kg} / \mathrm{day})$. Subsequently, a dose of $4.7 \times 10^{7} \mathrm{cell} / \mathrm{s} / \mathrm{kg}$ obtained from bone marrow was infused.

As part of the prophylaxis for graft-versus-host disease (GvHD), immunosuppression was used based on cyclosporine (CsA, $3 \mathrm{mg} / \mathrm{kg} / \mathrm{day}$ ) and methotrexate (15 mg/m $/ \mathrm{m}^{2}$ day +1 and $10 \mathrm{mg} / \mathrm{m}^{2}$ day on days $+1,+3$, $+5,+7$, and +11 ). However, due to the lack of graft data on day +22 , the calcineurin inhibitor dose was decreased, continuing with stimulation using granulocyte stimulating factor (Filgrastim). On day +27 , granulocytic graft data with a total neutrophil count of $1200 / \mu \mathrm{L}$ were observed. On day +35 , the patient showed $100 \%$ chimerism. Therefore, the dose of Filgrastim was decreased, and treatment with platelet-stimulating factor (Eltrombopag) was added, which continued for 6 months. 


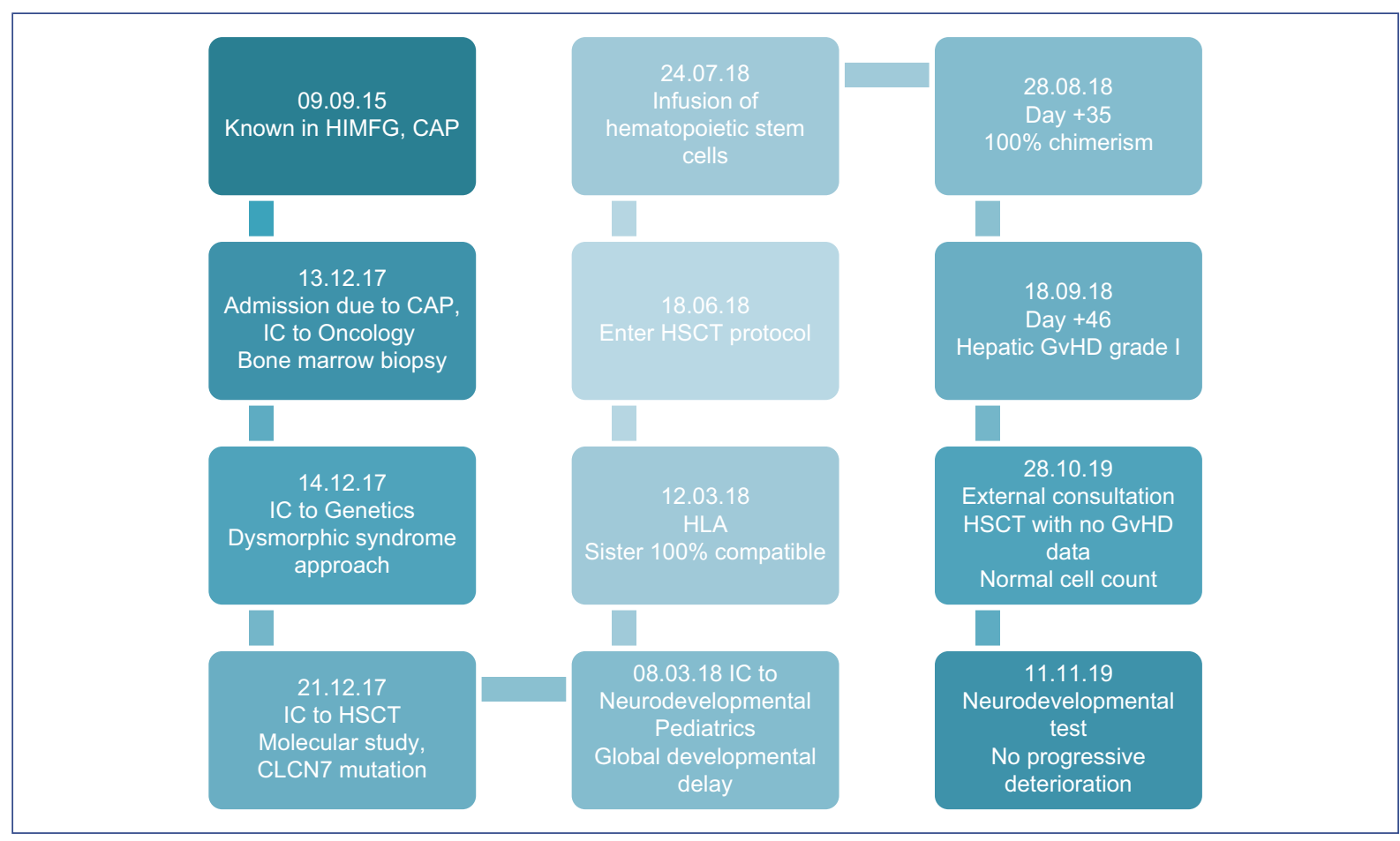

Figure 1. Chronological evolution of a patient with osteopetrosis. CAP: community-acquired pneumonia; GvHD: graftversus-host disease; HIMFG: Hospital Infantil de México Federico Gómez; HLA: human leukocyte antigen; HSCT: hematopoietic stem cell transplantation; IC: interconsultation.

During this period, the patient developed pneumonitis -requiring supplemental oxygen support through nasal prongs and inhaled steroid management-and presented hypercalcemia and hyperphosphatemia-which responded to management with hydration, forced diuresis, and phosphorus chelator, with no other complications. Subsequently, on day +46 , Grade II acute GvHD was diagnosed, supported by altered liver function tests with elevated bilirubin, for which treatment with methylprednisolone $(1 \mathrm{mg} /$ $\mathrm{kg} / \mathrm{day}$ ), cyclosporine, and ursodeoxycholic acid was administered. The treatment was gradually decreased according to the clinical course and CsA levels. Due to the adequate response to treatment, it was possible to withdraw immunosuppressive drugs (currently, the patient is not immunosuppressed).

According to the follow-up protocol, a periodic quantification of chimerism was carried out (on days $+15,+21$, $+28,+35,+100$, and +150 ) to verify the transplant graft. On day +15 , a chimera of $16.6 \%$ was found; subsequently, on day +21 , the percentage increased to $59.88 \%$, and on days $+35,+100$, and +150 after HSCT, $100 \%$ chimerism was documented (Fig. 2). At present, at 5 years of age, the patient continues in monthly outpatient follow-up and is in the process of entering preschool education. Furthermore, cell numbers are normal, with no platelet-stimulating factor or erythropoietin requirement, no GvHD data, and deferasirox treatment to avoid iron overload. Due to delayed growth, a weight of $14.2 \mathrm{~kg}(\mathrm{PZ}-2)$, and a height of $90 \mathrm{~cm}$ $(\mathrm{PZ}-3)$ at 5 years and 3 months of age, the patient is being followed up by the endocrinology service. The patient maintains a visual capacity with a slight deficit but no progression and under ophthalmology service follow-up.

In addition, the patient undergoes an annual audiological evaluation, with no apparent deficit. As part of the follow-up, the EDI test that reported significant developmental delay improved compared to the previous results. An increase in the score of six evaluated domains was observed, finding that the personal-social and adaptive sphere significantly improved. Since the patient showed no added neurological deficit and an improvement was reported in neurodevelopmental tests, a new neurological imaging study was not considered necessary at the time. At present, the patient is being monitored by the neurodevelopment and neurology service.

\section{Discussion}

Infantile osteopetrosis is a rare hereditary disease, with a characteristic phenotype of short stature, 


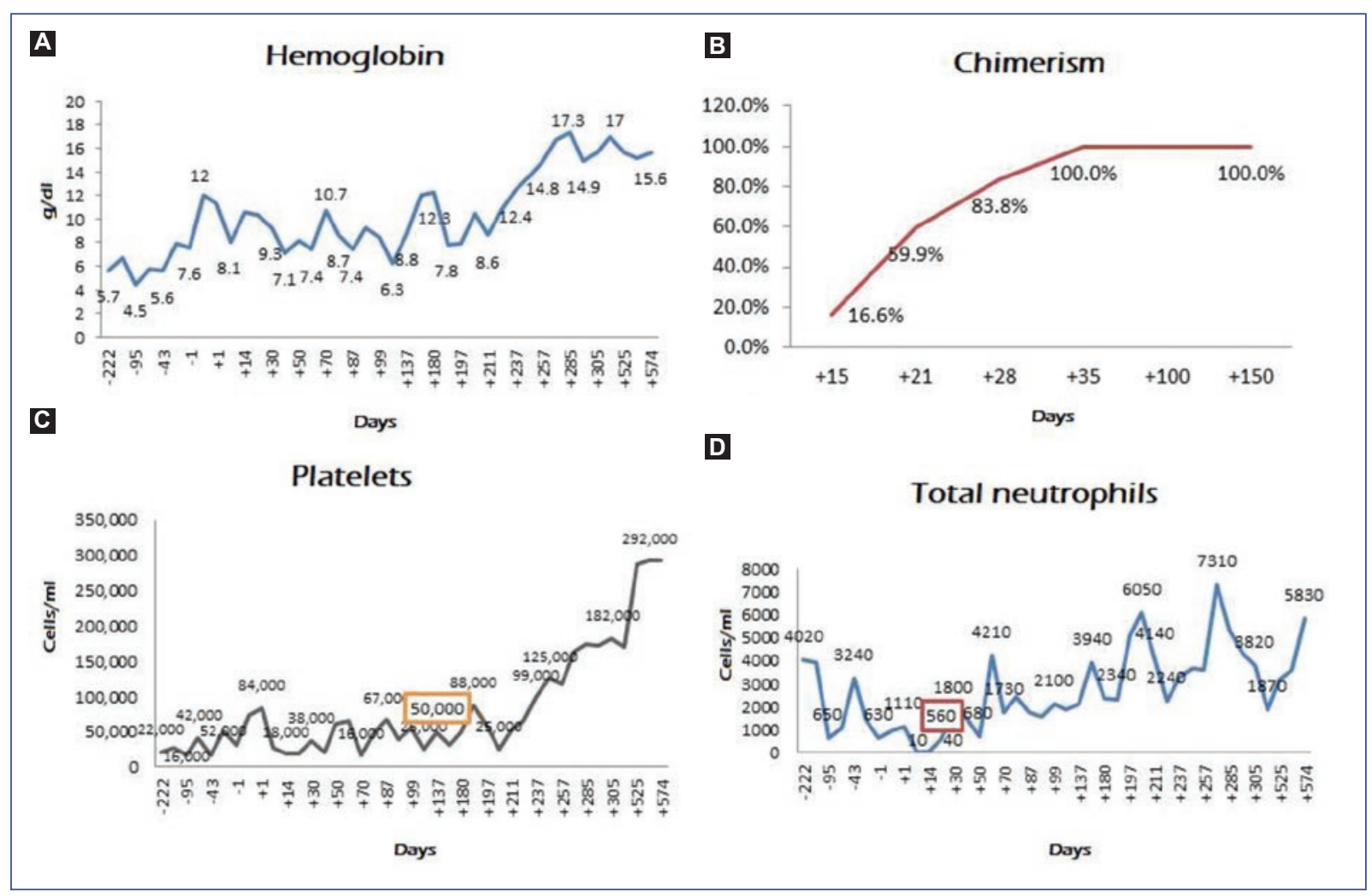

Figure 2. Laboratory studies of the patient with post-transplant osteopetrosis. A. Hemoglobin value after transplantation. B. Molecular chimerism after transplantation. C. Platelet value after transplantation. D. Granulocytic value after transplantation.

hypocalcemia, fractures, compression neuropathy, and pancytopenia; it is caused by the failure in the development and function of osteoclasts. We present the case of a 5-year-old male with a CLCN7 gene mutation and a 1-year follow-up after Allo-HSCT. Because osteopetrosis is caused by a defect in the osteoclasts derived from the hematopoietic cell line, bone marrow transplantation is the definitive treatment. Our patient underwent Allo-HSCT at 3 years and 9 months of age and currently has normal cell counts. The skeletal deformities and bone sclerosis shown on the X-rays improved since treatment (Fig. 3). Since the first approach, this patient exceeded the 3-year life expectancy reported for osteopetrosis patients with the CLCN-7 mutation (Table 1). Over 600 days after the transplant, the patient has shown a favorable evolution, decreasing the need for transfusions and hospitalization. Furthermore, skeletal deformities and neurodevelopmental tests have improved, leading to a better quality of life.

Severe osteopetrosis with increased bone mineral density results from the absence of osteoclasts, caused by a defect in the differentiation of osteoclast precursors or by dysfunctional osteoclasts. Therefore, the definitive treatment must be the transplant of hematopoietic stem cells with a bone marrow origin to obtain bone marrow-derived osteoclasts.

Abnormal bone expansion interferes with hematopoiesis, causing life-threatening pancytopenia and extramedullary hematopoiesis in the spleen and liver, and frequent hepatosplenomegaly. This patient presented pancytopenia at diagnosis. Initially, an infiltrative syndrome was suspected but ruled out; later, osteopetrosis was diagnosed.

Patients with some mutation usually have neurosensory, visual, and auditory alterations caused by bone compression $^{12}$. In this patient, cortical atrophy accompanied with secondary ventricular dilation and bilateral visual pathway conduction alteration was documented, consistent with some reports in which MRls show myelination delay and progressive cortical and subcortical atrophy ${ }^{13}$. The leading causes of death in these patients are infections, bleeding, and severe anemia, and allogeneic hematopoietic progenitor cells transplant is the only curative option ${ }^{14}$. A 5-year survival rate of $73 \%$ is reported when $100 \%$ compatible donor transplant is performed ${ }^{15}$. Risk of death increases in the first 


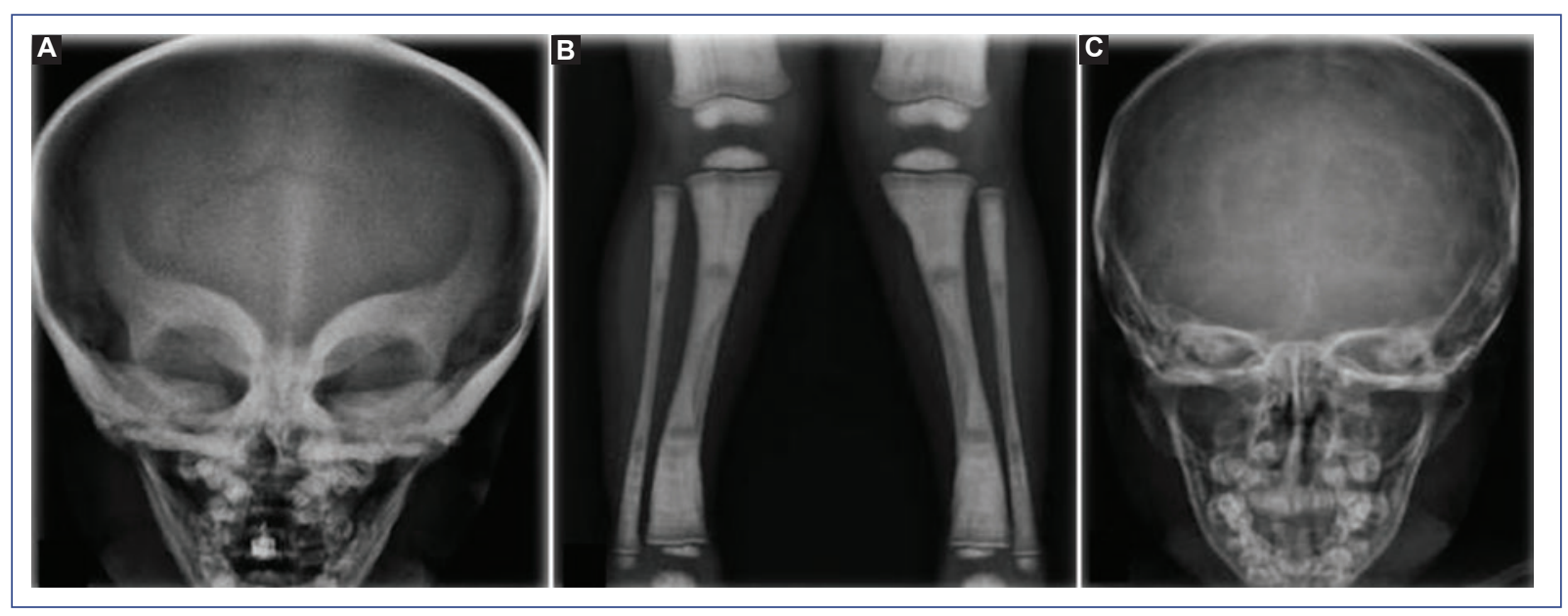

Figure 3. Osteopetrosis patient imaging studies. A. X-ray of the skull showing mask sign. Predominant generalized bone hyperdensity is observed at the base of the skull (before transplantation). B. X-ray of tibia and fibula with the bone within a bone sign. C. X-ray of the skull after transplantation with decreased bone hyperdensity.

10 years if Allo-HSCT is not performed due to the suppression of hematopoiesis in the bone marrow and its consequences.

The highest survival is reported in patients who received a transplant $100 \%$ HLA compatible of a related donor. The 5- and 10-year survival in patients with $100 \%$ compatible related donor Allo-HSCT is $62 \%$ in both, while for transplant of unrelated donor decreases to $42 \%$ and $39 \%$, respectively. Therefore, it is of critical importance to obtain a related donor Allo-HSCT ${ }^{16}$. As for the complications that can occur after transplant in patients with osteopetrosis, primary and late graft failure has been described. In the present case, we observed delayed platelet engraftment with an adequate response to the platelet-stimulating factor. This complication imposes a higher mortality risk in transplanted patients ${ }^{17}$.

The leading cause of transplant-related mortality is graft failure, accounting for $50 \%$ of deaths in transplants from related donors and $43 \%$ from unrelated donors.

Allo-HSCT improves bone lesions within 2 months, and they resolve entirely within a year of transplant ${ }^{18}$. However, survivors reported that only $7 \%$ experience improvement regarding the optical damage, $69 \%$ show no progression, and $25 \%$ show deterioration.

This clinical case generates essential information about HSCT and osteopetrosis despite the age at the time of diagnosis because the evolution has been favorable. Therefore, we emphasize the importance of clinical suspicion for timely diagnosis and treatment. As no documented evidence exists in our country, it is imperative to generate this kind of reports due to the remarkable improvement that a timely treatment means in patients' quality of life and survival.

There is only one previous report in our country, documenting a 9-month-old patient who required a second transplant at 13 months of age, using the umbilical cord as a cellular source on both occasions ${ }^{19}$. It is necessary to continue investigating and reporting these cases to enrich this knowledge.

In this case, we emphasize the importance of early diagnosis. Suspicion of the disease in a patient with pancytopenia, craniofacial and thoracic dysmorphia, hepatosplenomegaly, and radiological evidence of bone sclerosis should prompt a comprehensive approach and early osteopetrosis diagnosis. Therefore, timely interventions and early treatment with Allo-HSCT could be established to improve the patient's clinical conditions. It is essential to perform an Allo-HSCT, preferably before 1 year of age, to avoid progressive and irreversible neurological damage and decrease mortality. It has been shown that patients who have $100 \%$ compatible donor for Allo-HSCT have a 5-year survival of $73 \%$. However, with an unrelated donor, survival of $40 \%$ has been reported.

Timely Allo-HSCT has an impact on the patient's prognosis and quality of life. It is possible to perform late Allo-HSCT in a patient with mild neurosensory deficits and achieve a cure for osteopetrosis, stop the progression of neurological damage, and achieve an adequate quality of life on the condition where a multidisciplinary treatment is available. 


\section{Ethical disclosures}

Protection of human and animal subjects. The authors declare that no experiments were performed on humans or animals for this study.

Confidentiality of data. The authors declare that they have followed the protocols of their work center on patient data publication.

Right to privacy and informed consent. The authors have obtained the written informed consent of the patients or subjects mentioned in the article. The corresponding author has this document.

\section{Conflicts of interest}

The authors declare no conflicts of interest.

\section{Funding}

None.

\section{References}

1. Wu CC, Econs MJ, DiMeglio LA, Insogna KL, Levine MA, Orchard PJ, et al. Diagnosis and management of osteopetrosis: consensus guidelines from the Osteopetrosis Working Group. J Clin Endocrinol Metab. 2017;102:3111-23.

2. El-Sobky TA, Elsobky E, Sadek I, Elsayed SM, Khattab MF. A case of infantile osteopetrosis: the radioclinical features with literature update. Bone Rep. 2015;4:11-6.

3. Srinivasan M, Abinun M, Cant AJ, Tan K, Oakhill A, Steward CG. Malignant infantile osteopetrosis presenting with neonatal hypocalcaemia. Arch Dis Child Fetal Neonatal Ed. 2000;83:F21-3.

4. Kasper D, Planells-Cases R, Fuhrmann JC, Scheel O, Zeitz O, Ruether K, et al. Loss of the chloride channel CIC-7 leads to lysosomal storage disease and neurodegeneration. EMBO J. 2005;24:1079-91.
5. Tolar J, Teitelbaum SL, Orchard PJ. Osteopetrosis. N Engl J Med. 2004;351:2839-49.

6. Stark Z, Savarirayan R. Osteopetrosis. Orphanet J Rare Dis. 2009;4:5.

7. Penna S, Capo V, Palagano E, Sobacchi C, Villa A. One disease, many genes: implications for the treatment of osteopetroses. Front Endocrinol (Lausanne). 2019;10:85.

8. Waguespack SG, Hui SL, White KE, Buckwalter KA, Econs MJ. Measurement of tartrate-resistant acid phosphatase and the brain isoenzyme of creatine kinase accurately diagnoses type II autosomal dominant osteopetrosis but does not identify gene carriers. J Clin Endocrinol Metab. 2002;87:2212-7.

9. Kornak U, Schulz A, Friedrich W, Uhlhaas S, Kremens B, Voit T, et al. Mutations in the a3 subunit of the vacuolar $\mathrm{H}(+)$-ATPase cause infantile malignant osteopetrosis. Hum Mol Genet. 2000;9:2059-63.

10. Sobacchi C, Frattini A, Orchard P, Porras O, Tezcan I, Andolina M, et al. The mutational spectrum of human malignant autosomal recessive osteopetrosis. Hum Mol Genet. 2001;10:1767-73.

11. Steward CG, Pellier I, Mahajan A, Ashworth MT, Stuart AG, Fasth A, et al. Severe pulmonary hypertension: a frequent complication of stem cell transplantation for malignant infantile osteopetrosis. $\mathrm{Br} \mathrm{J}$ Haematol. 2004;124:63-71.

12. Steward CG. Neurological aspects of osteopetrosis. Neuropathol Appl Neurobiol. 2003;29:87-97.

13. Maranda B, Chabot G, Décarie JC, Pata M, Azeddine B, Moreau A, et al. Clinical and cellular manifestations of OSTM1-related infantile osteopetrosis. J Bone Miner Res. 2008;23:296-300.

14. Stepensky P, Grisariu S, Avni B, Zaidman I, Shadur B, Elpeleg O, et al. Stem cell transplantation for osteopetrosis in patients beyond the age of 5 years. Blood Adv. 2019;3:862-8.

15. Driessen GJ, Gerritsen EJ, Fischer A, Fasth A, Hop WC, Veys P, et al. Long-term outcome of haematopoietic stem cell transplantation in autosomal recessive osteopetrosis: an EBMT report. Bone Marrow Transplant. 2003;32:657-63.

16. Orchard PJ, Fasth AL, Le Rademacher J, He W, Boelens JJ, Horwitz EM, et al. Hematopoietic stem cell transplantation for infantile osteopetrosis. Blood. 2015;126:270-6.

17. Ramírez P, Brunstein CG, Miller B, Defor T, Weisdorf D. Delayed platelet recovery after allogeneic transplantation: a predictor of increased treatment-related mortality and poorer survival. Bone Marrow Transplant. 2011;46:981-6.

18. Cheow HK, Steward CG, Grier DJ. Imaging of malignant infantile osteopetrosis before and after bone marrow transplantation. Pediatr Radiol. 2001;31:869-75.

19. González LL, Jaime PJ, Cantú RO, Mancias GC, Gutiérrez AH, Herrera GJ, et al. Allogeneic hematopoietic stem cell transplantation using a reduced-intensity conditioning regimen in infants: experience at a single institution in Mexico. Pediatr Hematol Oncol. 2008;25:39-47. 